\title{
Unlawful Occupiers, Eviction and the National State of Disaster: Considering South Africa's Emergency Legislation and Jurisprudence During COVID-19
}

\author{
Felix Dube* $\odot$ \\ North-West University, Potchefstroom, South Africa \\ Felix.Dube@nwu.ac.za \\ Anél du Plessis** \\ North-West University, Potchefstroom, South Africa \\ Anel.DuPlessis@nwu.ac.za
}

\begin{abstract}
This article analyses how emergency regulations protected persons living in urban poverty, particularly unlawful occupiers, from eviction during the COVID-19 pandemic in South Africa. It is set against the socio-economic and environmental effects of unlawful occupiers being forced onto the streets through evictions. It examines the judicial interpretation and application of the COVID-19 regulations on the prohibition of the eviction of unlawful occupiers, together with remedies for compensation for demolished dwellings. Ultimately, the article shows that the regulatory and judicial responses to the pandemic were pro-poor and sought to protect human dignity, the right to life, and the right to an environment that is not detrimental to human health and well-being. The responses safeguarded access to housing at a time when many vulnerable people could have been rendered homeless by eviction and the demolition of their dwellings.
\end{abstract}

\section{Keywords}

Unlawful occupiers, eviction, COVID-19, spatial justice, consequential geography, South Africa

\footnotetext{
* LLB, LLM, LLD. Postdoctoral research fellow, Faculty of Law, North-West University, South Africa.

** BA (law), LLB, LLM, LLD. Professor of law and South African research chair in cities, law and environmental sustainability, North-West University, South Africa.

This work is based on research conducted with the financial support of the National Research Foundation of South Africa (grant no 115581). All views and errors are the authors' own.
} 


\section{INTRODUCTION}

The COVID-19 pandemic and the measures implemented by the South African government to curb its spread caused suffering to many people, particularly persons living in urban poverty. In its attempts to slow the spread of the virus by reducing overcrowding and enhancing social distancing, the government, like some of its counterparts worldwide, threatened persons living in informal settlements with mass removals, prompting the UN special rapporteur on the right to housing to implore governments to desist from such large-scale operations during the pandemic. ${ }^{1}$ In April 2020, the government heeded the special rapporteur's call by announcing the cancellation of a planned "de-densification" process that would have seen mass removals of people living in some informal settlements on the pretext of easing congestion and allowing for social distancing. The government committed to work with stakeholders in a united effort against the spread of COVID-19 in informal settlements. In addition to the enhanced provision of water, sanitation equipment and other necessities to informal settlements, the government appointed contractors to fast-track the building of housing units to ease the congestion in informal settlements, without forcibly relocating people. ${ }^{2}$

However, the pandemic exposed the magnitude of the housing and basic service delivery crisis. For example, in the City of Cape Town (the City), where access to land and housing are serious issues, people increasingly resorted to self-help during the pandemic. Land invasions intensified during lockdown, reaching over 252 recorded instances, while protests over housing exceeded $115 .^{3}$ In response, the City demolished over 60,000 informal housing structures during lockdown. ${ }^{4}$ The City's actions, which entailed evictions during winter without the provision of alternative accommodation, violated the lockdown regulations and left many unlawful occupiers homeless and stranded in the cold.

This article is a doctrinal analysis of recent developments in South African law and jurisprudence on the protection of unlawful occupiers from eviction during the different COVID-19 alert levels. It is set against the backdrop of the consequent socio-economic and environmental effects when poor people living in urban poverty are evicted. The article examines the judicial

1 L Farha "COVID-19 guidance note: Prohibition of evictions" (28 April 2020) UN Human Rights Special Procedures, available at: <https://www.ohchr.org/Documents/Issues/Hous ing/SR_housing_COVID-19_guidance_evictions.pdf> (last accessed 23 June 2021).

2 "Minister Lindiwe Sisulu on government's response to coronavirus Covid-19 pandemic" (29 April 2020, Government of the Republic of South Africa media statement), available at: <https://www.gov.za/speeches/minister-lindiwe-sisulu-government\%E2\%80\%99s-res ponse-coronavirus-covid-19-pandemic-29-apr-2020> (last accessed 23 June 2021).

$3 \mathrm{~K}$ Palm "CoCT sees major spike in land invasions, says housing opportunities under threat" (17 September 2020) Eyewitness News, available at: <https://ewn.co. za/2020/09/17/coct-sees-major-spike-in-land-invasions-says-housing-opportunities-underthreat> (last accessed 20 September 2021). Ibid. 
interpretation and application of the COVID-19 regulations prohibiting the eviction of unlawful occupiers and the demolition of their dwellings, as well as remedies for compensation. Ultimately, it shows that the regulatory and judicial response of the South African government to the pandemic was pro-poor and sought to protect human dignity, the right to life, and the right to an environment not detrimental to human health and well-being, and was designed to safeguard access to housing at a time when many vulnerable people could have been rendered homeless.

\section{THE EVICTION OF UNLAWFUL OCCUPIERS IN SOUTH AFRICAN LAW}

Under the Prevention of Illegal Eviction from and Unlawful Occupation of Land Act 19 of 1998 (PIE), South African law defines an "unlawful occupier" as, inter alia, "a person who occupies land without the express or tacit consent of the owner or person in charge, or without any other right in law to occupy such land". ${ }^{5}$ PIE imposes stringent measures for the eviction of unlawful occupiers and stipulates that such evictions can only occur when authorized by a court after a hearing and only at least 14 days after notice has been given to the unlawful occupiers. ${ }^{6}$ When eviction of unlawful occupiers is sought by an organ of state, the court must consider the availability of suitable alternative accommodation or other land to which the people will be moved. ${ }^{7}$ Thus, a lawful eviction is one that is authorized by a court and carried out in accordance with that court order. However, the COVID-19 pandemic saw a sharp rise in the number of unauthorized evictions in South Africa. ${ }^{8}$ The extent of the evictions during the pandemic prompted the government to promulgate regulations to protect unlawful occupiers from eviction during lockdown.

\section{PROHIBITION OF THE EVICTION OF UNLAWFUL OCCUPIERS DURING LOCKDOWN}

\section{Alert Levels 3, 4 and 5}

On 16 April 2020, the government promulgated COVID-19 regulations to prohibit evictions during Alert Level 5 of the lockdown. Regulation 11CA stipulated that "no person may be evicted from their place of residence,

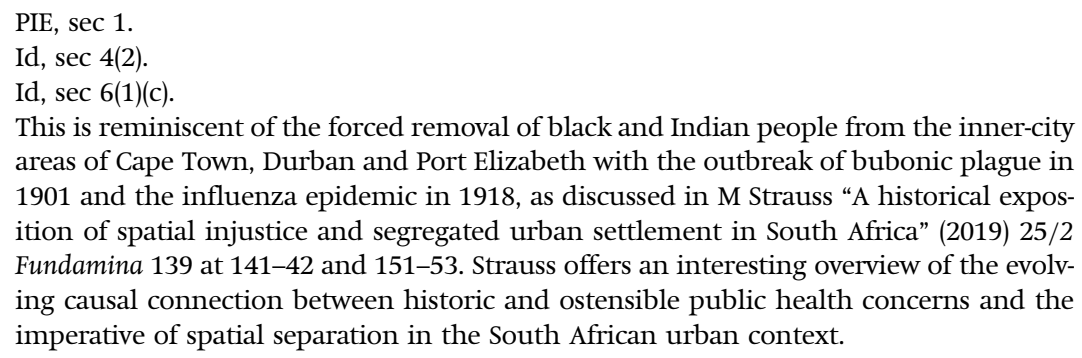
areas of Cape Town, Durban and Port Elizabeth with the outbreak of bubonic plague in 1901 and the influenza epidemic in 1918, as discussed in M Strauss "A historical exposition of spatial injustice and segregated urban settlement in South Africa" (2019) 25/2 Fundamina 139 at 141-42 and 151-53. Strauss offers an interesting overview of the evolving causal connection between historic and ostensible public health concerns and the imperative of spatial separation in the South African urban context. 
regardless of whether it is a formal or informal residence or a farm dwelling, for the duration of the lockdown". ${ }^{9}$ This provision was an effective moratorium on evictions of unlawful occupiers. It did not give the courts discretion to hear or grant any eviction applications. Alert Level 4 commenced on 1 May 2020. ${ }^{10}$ The Alert Level 4 Regulations stipulated that the courts could grant orders for the eviction of unlawful occupiers and other persons from land in accordance with PIE and the Extension of Security Tenure Act (ESTA), ${ }^{11}$ provided that such an order could be stayed and suspended until the last day of the application of Alert Level $4 .{ }^{12}$ The only exception was when a court deemed that staying or suspending such an eviction order would not be just and equitable. On 28 May 2020, the minister determined that Alert Level 3 would apply from 1 June $2020^{13}$ and accordingly amended the regulations and directives issued under section 27(2) of the Disaster Management Act. ${ }^{14}$ The Alert Level 3 Regulations stipulated that "a person may not be evicted from his or her land or home during the Alert Level 3 period". ${ }^{15}$ However, as under the Alert Level 4 Regulations, there were exceptions. For example, if a court determined that suspending or staying the eviction order until the last day of the Alert Level 3 period would not be just and equitable, it could authorize an eviction, provided that it fully considered PIE and ESTA. This meant that, when a court authorized an eviction during the pandemic, it had to ensure that the decision met the legal thresholds in PIE and ESTA as they existed before the pandemic.

\section{Alert Levels 1 and 2}

Alert Level 2 commenced on 18 August 2020. ${ }^{16}$ The minister accordingly amended the COVID-19 Regulations. ${ }^{17}$ The Alert Level 2 Regulations prohibited evictions and the demolition of places of residence without court authorization. ${ }^{18}$ The regulations required the courts to consider, inter alia, the following factors before granting eviction and demolition orders: the public interest in preventing homelessness by ensuring everyone has access to a place of residence; the regulations prohibiting the movement of persons;

9 Reg 11CA of the Amendment of Regulations Issued in Terms of Section 27(2) in No R 465 in GG 43232 of 16 April 2020.

10 Regulations Issued in Terms of Section 27(2) of the Disaster Management Act 57 of 2002 in GNR 480 in GG 43258 of 29 April 2020 (Alert Level 4 Regulations), reg 15.

11 Act 62 of 1997

12 Alert Level 4 Regulations, reg 19.

13 Determination of Alert Level and Hotspots in GN 608 in GG 43364 of 28 May 2020.

14 Amendment of Regulations Issued in Terms of Section 27(2) in GN 608 in GG 43364 of 28 May 2020 (Alert Level 3 Regulations).

15 Id, reg 36.

16 See the Determination of Alert Level in GN 891 in GG 43620 of 17 August 2020.

17 Amendment of Regulations Issued in Terms of Section 27(2) in GN 891 in GG 43620 of 17 August 2020 (Alert Level 2 Regulations).

Id, reg 53. 
the impact of the pandemic on the persons to be evicted or whose dwellings were to be demolished; the balance of convenience and the need to avoid prejudice to affected parties; restrictions to access to legal services; and the availability of immediate access to suitable alternative accommodation. ${ }^{19}$

The Alert Level 2 Regulations placed stringent requirements on persons seeking the eviction of unlawful occupiers and the demolition of their dwellings. The regulations required the courts, when determining whether to grant eviction or demolition orders, to "request a report from the responsible member of the executive regarding the availability of any emergency accommodation". ${ }^{20}$ On 18 September 2020, the minister withdrew the determination of Alert Level 2, moved South Africa to Alert Level 1 and promulgated the Alert Level 1 Regulations. ${ }^{21}$ Regulation 70 dealt with evictions and the demolition of places of residence. It contained almost all of the Alert Level 2 provisions, in so far as it prohibited the eviction and demolition of places of residence for the duration of the national state of disaster unless a competent court issued an order authorizing such evictions or demolitions. The courts could hear eviction or demolition applications, and could suspend or stay orders for their execution. ${ }^{22}$ The Alert Level 1 Regulations also listed the specified factors under Alert Level 2 and required the courts, where applicable, to request any relevant reports from other parties and from the cabinet member on whether emergency accommodation was available, before authorizing an eviction or demolition. Despite the moratorium on evictions and the demolition of places of residence, and despite the government's reconfigured approach to assisting people living in informal settlements during lockdown, reports of several unlawful evictions in informal settlements emerged, particularly in the City, in which the court observed that the evictions were effected with brutal force reminiscent of the apartheid era. ${ }^{23}$

\section{JUDGMENTS AGAINST EVICTION}

\section{Community of Hangberg $v$ City of Cape Town}

\section{Background}

The City demolished a dwelling (a "Wendy house"), constructed by one Ginola Phillips, twice (first on 11 June 2020 and then again on 19 June 2020). Acting together with the occupier, the Hangberg community approached the High Court for relief on the basis that the City had unlawfully evicted him from "his place" without following the legal process. ${ }^{24}$ It was argued that $\mathrm{Mr}$

\footnotetext{
19 See ibid.

20 Id, reg 53(3).

21 Amendment of Regulations Issued in Terms of Section 27(2) in GN 999 in GG 43725 of 18 September 2020 (Alert Level 1 Regulations).

22 Id, reg 70(2).

23 South African Human Rights Commission v City of Cape Town [2021] 2 SA 565 (WCC) (Qolani), para 1.

24 Community of Hangberg $v$ City of Cape Town [2020] ZAWCHC 66, para 4.
} 
Phillips was entitled to restoration of his structure because "he was spoliated of possession of his home and accordingly unlawfully evicted". ${ }^{25}$ The City did not dispute that PIE applied but averred that the Wendy house was not a home because Mr Phillips did not sleep in it most of the time. The City further alleged that he had previously been residing with his mother elsewhere and that, when the structure was demolished for the second time, it had been only partially rebuilt. Furthermore, the City alleged that its failure to obtain a court order before evicting Mr Phillips was due to impossibility in that it "could not access the courts due to the COVID-19 lockdown directives which restrained eviction proceedings". ${ }^{26}$ The contentions were admissions that the City had acted unlawfully by taking the law into its own hands. The legislation was clear that no person could be evicted without a court order. ${ }^{27}$

\section{Reasons for judgment}

The court rejected all of the City's contentions and decided the matter on the basis of regulation 36(1) of the Alert Level 3 Regulations. The court noted that the pandemic placed poor communities under extreme hardship and that there was increasing unemployment, homelessness and escalating poverty, among other manifestations of the hardship wrought by the pandemic on vulnerable communities. ${ }^{28}$ In this case, there was no explanation for why the City was eager to evict Mr Phillips so urgently, except for a not-so-plausible averment that the Wendy house had been built on an environmentally protected sand-dune. ${ }^{29}$ The court decided that a remedy for the destruction of $\mathrm{Mr}$ Philips's Wendy house lay in mandament van spolie, which essentially requires the restoration of property to persons who had previously been in possession of it. ${ }^{30}$ After noting that unlawful evictions infringed the right to housing and human dignity, in contradiction of the founding constitutional values aimed at correcting past injustices, marginalization and deprivation, ${ }^{31}$ the court concluded that the City's actions were "a sore and painful reflection of a failure to appreciate the plight of our poor communities, the hardships suffered and what can probably be described as objectifying the indigent as having no individual rights worthy of recognition". ${ }^{32}$

The judge further noted that the City had acted overzealously in demolishing the Wendy house twice and that, in doing so, the City had acted callously. The court said that "the demolition was indeed also inhuman, heartless, and done with scant regard of his safety, security and health particularly in light of

25 Ibid.

26 Id, para 6.

27 See PIE, secs 4, 5 and 6.

28 Community of Hangberg, above at note 24, para 6.

29 Id, para 11.

30 Id, para 8.

31 Id, para 9.

32 Id, para 10. 
the COVID-19 health pandemic". ${ }^{33}$ The judgment was a serious indictment on the City. The court not only rebuked the City, but also implored it to bear in mind that resources were constrained by the pandemic and that there was a constitutional obligation on the City to govern and utilize its resources constitutionally and lawfully. The court noted that the violation of the Bill of Rights through unlawful evictions would not be permitted in a democratic South Africa. ${ }^{34}$ Lastly, the court noted that the Hangberg Community had supported the application and that, in doing so, the community had illustrated ubuntu [humanity to others] and the spirit of "solidarity to the plight of housing". ${ }^{35}$ In contrast, the City had failed to bear these imperatives in mind. The court granted the mandament van spolie and directed the City to rebuild the Wendy house to the same size and dimensions as the destroyed structure within 48 hours and to file a report, accompanied with an affidavit, to the registrar of the court by 14:00 on 17 July 2020 , confirming that the structure had been rebuilt and handed over to Mr Phillips. The court also awarded costs against the City as an expression of its displeasure and disapproval of the City's actions.

\section{Implications for the City of Cape Town}

The court's judgment had several implications. First, if the City wanted to evict Mr Philips, it would have to apply to the court for an order and satisfy the court that it had complied with all the provisions of PIE. One of the requirements of PIE is that the City would have had to prove that it had provided Mr Philips with adequate and suitable accommodation. This would also entail proving to the court that the eviction was reasonably necessary in the circumstances. The argument about the environmentally protected sand-dune would not hold, given that Mr Philips had built his Wendy house in a community of structures on the same dune. Surely, one more Wendy house would not imperil the sand dune. Since there were other structures in Hangberg adjacent to Mr Philips's dwelling, the City would have to prove why it was so important to pursue Mr Phillips with so much vigour. Given the historical circumstances identified by the court, it would be hard for the City to prove this. The court believed that, instead of wasting scarce funds pursuing Mr Phillips, it would be wise for the City to leave Mr Philips alone. The second implication of the judgment was that it made it possible for other unlawfully evicted persons to apply to the court to have their demolished structures rebuilt by the City. Depending on the circumstances of each case, the courts were likely to grant such requests, given their constitutional obligation to safeguard human rights. In fact, the court did this in South African Human Rights Commission $v$ City of Cape Town (Qolani), ${ }^{36}$ as discussed below.

33 Ibid.

34 Ibid.

35 Id, para 13.

36 Above at note 23. 


\section{Further observations}

There is a question to ask, however, about the legal remedy granted by the court: was it competent for the court to order the City to rebuild an illegal structure and to vindicate the rights of an unlawful occupier who had been told many times that he was not permitted to build the structure? The structure had been demolished twice by the City's Anti-Land Invasion Unit (ALIU). Mr Phillips knew that his conduct was illegal. Although the community of Hangberg supported him, that did not mitigate the illegality of his conduct. Nevertheless, he proceeded to rebuild the structure in open defiance of the City. Mr Phillips had violated the law and was, at common law, precluded from seeking the protection of the court and its assistance to perpetuate his unlawful conduct. It is established in case law that a "litigant with dirty hands is not entitled to expect, or to receive, clean justice from the Court". ${ }^{37}$ Since the adoption of South Africa's Constitution of 1996 (the Constitution), other courts have been applying the "dirty hands" principle with due regard to constitutional values and the need to protect vulnerable groups from exploitation. In Kylie $v$ Commission for Conciliation Mediation and Arbitration and Others, the court recognized that, although the common law position was that the courts should, as a matter of principle, nullify contracts arising from and associated with prohibited conduct and dismiss constitutional claims arising from conduct that is prohibited in legislation, the courts have discretion to grant just and equitable orders in favour of a party with "dirty hands" if doing so would prevent manifest injustice. ${ }^{38}$

In Community of Hangberg, the court exercised discretion to grant Mr Phillips the mandament van spolie. The court did so to protect the rights of an indigent person from being trampled on by the powerful City. The judgment also sent a message across South Africa that the courts would not tolerate illegal evictions, even if carried out against unlawful occupiers who knowingly and deliberately flout by-laws and legislation that prohibit land invasions. Whether the court order was just and equitable should be determined with due regard to the interests of justice, and the need to vindicate the rule of law and to protect the fundamental values of human dignity, equality and freedom from infringement. In the judgment, the court chose to protect human dignity and to promote the right to housing, even if doing so perpetuated illegality.

\section{South African Human Rights Commission v City of Cape Town ${ }^{39}$} Facts

This case was heard on 20 and 21 August 2020 and decided on 25 August 2020. The judgment was an example of swift justice delivered by a court in defence of unlawful occupiers against unlawful evictions during the pandemic, in contravention of the COVID-19 regulations. In this article, this case is referred

37 Khaile v Administrator Board, Western Cape 19831 SA 473 (C) at 480.

3820104 SA 383 (LAC), paras 52 and 56.

39 Above at note 23. 
to as Qolani, after the name of the third applicant, Bulelani Qolani, the unlawful occupier after whose unlawful eviction the first and second applicants instituted legal action. Other unlawful occupiers of ER544, Portion 1, Emfuleni, also intervened in the proceedings. The legal proceedings commenced after a video emerged on social media showing members of ALIU dragging a naked man out of a shack and demolishing the dwelling. ALIU is a specialized unit tasked by the City to determine, "without a court order, which structures should be demolished, primarily in informal settlements and on land that becomes occupied". ${ }^{40}$ The court heard that, from April 2020, ALIU and private contractors had, on the City's instructions, demolished the dwellings of unlawful occupiers in the Empolweni Informal Settlement in Makhaza, Khayelitsha.

\section{Legal issues}

The court was called upon to grant interdictory relief "to inject judicial oversight into evictions and demolitions during the national state of disaster in informal settlements in particular, where the most vulnerable reside". ${ }^{41}$ To this end, the court was asked to interdict (in part A of the application) the City and its private contractors from evicting unlawful occupiers and demolishing such dwellings (whether known as huts, shacks, tents or by other similar names) without court orders, regardless of whether or not the dwellings were occupied. The interdict was sought for the City for the duration of the national state of disaster. ${ }^{42}$ The court was also asked to order the City and its contractors to ensure that, when a court order authorized evictions or demolitions, those evictions or demolitions would be carried out lawfully and with due regard to the need to uphold the dignity of the affected persons, and without using excessive force or destroying the personal possessions of the unlawful occupiers. The court was also asked to order the South African Police Service to ensure that, when it participated in enforcing eviction or demolition orders, its members would act lawfully and with due regard to the constitutional obligation to respect human dignity. Importantly, the court was asked to interdict and restrain the City from considering, adjudicating and awarding bids for the demolition of illegal and informal structures in the City's jurisdiction for the duration of the national state of disaster. ${ }^{43}$

\section{Legal arguments}

The applicants relied on four rights: the right not be evicted without a court order; ${ }^{44}$ the constitutional right not to be arbitrarily evicted; 45 the right to

\footnotetext{
40 Id, para 1.

41 Ibid.

42 Id, para 2.

43 Ibid.

44 PIE, sec 1(1).

45 Constitution, sec 26(3).
} 
access to courts; 46 and regulation 36 of the Alert Level 3 Regulations. ${ }^{47}$ ALIU argued that the dwellings that it had demolished were not occupied at the material time and that the unlawful occupiers were not protected under section 26(3) of the Constitution or PIE. It noted that it demolished complete structures and structures that were in various stages of construction. ${ }^{48}$ It was argued that, since the City had a right to counter-spoliate, it did not need a court order authorizing the evictions and the demolition of structures, which the City argued were not houses in the context of the right to access to housing. ${ }^{49}$ This was a fatal argument, as it ignored the principles laid down in Community of Hangberg. The argument also seemed to overlook the fact that on 17 April 2020 the High Court had granted an interim order against the City to return all building materials that it had confiscated from the properties in Empolweni and had authorized the occupiers to rebuild and occupy their structures for the duration of lockdown. ${ }^{50}$

\section{Reasons for judgment}

The court held that the applicants had succeeded in establishing a need for the vindication of their rights and interdicted the City from demolishing their unoccupied structures without court orders during the national state of disaster. ${ }^{51}$ With regard to the plight of unlawful occupiers living in urban poverty during the pandemic, the court stated:

"It is the poorest of the poor, the homeless, downtrodden and unemployed who seek refuge in informal settlements and erect structures to provide shelter. Whether such structures are complete, incomplete, or in the process of being built, they are capable of providing shelter from the elements especially during the winter season we are now experiencing. This is especially so during the catastrophic times we are forced to endure while the coronavirus pandemic rages. It is entirely apt for the courts to decide who is to be deprived of their shelter." ${ }^{52}$

The court was particularly moved by the continuing demolition of informal dwellings by the City without court orders and how this continued to subject thousands of people to arbitrary action. The court said these actions caused irreparable harm and homelessness by, inter alia, violating the dignity of the unlawful occupiers and imperilling their right to health. ${ }^{53}$ Despite the concerns about land incursions, the court held that the balance of convenience weighed in favour of the unlawful occupiers and that it was necessary 
to grant the interdict application to protect thousands of vulnerable people whom the City was threatening with homelessness during the COVID-19 pandemic. ${ }^{4}$ The court also held that the applicants had established the use of excessive force and other unlawful conduct by the City and ALIU when evicting them and that this necessitated an order to ensure that the constitutional rights to life, human dignity, freedom and security of the person were safeguarded, even in circumstances where a court would have granted an eviction or demolition order. ${ }^{55}$ The court was convinced that the "pattern of violent behaviour and the absence of any evidence that it will not be repeated is a reasonable apprehension of irreparable harm".56 To alleviate further suffering, the court ordered the South African Police Service to ensure that, when its members were present at evictions or demolitions, they would act constitutionally to prevent City and ALIU officials from acting unlawfully through the use of excessive force. ${ }^{57}$ The court further restrained the issuing of a demolitions tender to prevent the City from employing a service provider to demolish the dwellings of unlawful occupiers. ${ }^{58}$ The court further ordered the City to return all properties that it had seized from unlawful occupiers and to compensate each unlawful occupier with R2,000,000 (less than GBP100) for the loss of personal possessions as a result of the City's unlawful actions. ${ }^{59}$ In addition, the court ordered the City to pay some of the costs of the litigation. ${ }^{60}$

\section{THE RULE OF LAW AND THE CONSTITUTION DIRECTING MUNICIPALITIES' RESPONSE TO DISRUPTIVE RISK, URBAN INFORMALITY AND SPATIAL INJUSTICE}

In 2006, Lanford and du Plessis stated that, "[t]he world is facing what could fairly be described as a global epidemic of forced evictions, on an unprecedented scale". ${ }^{61}$ They used this metaphor to emphasize the frequency and intensity of forced evictions in the global north and south, and to point to the impact of forced evictions on people and livelihoods. Little would they be able to predict at the time what was yet to come and how a real global pandemic would turn the spotlight on how severely forced evictions affect people's lives, well-being and livelihoods in informal settings. The COVID-19 pandemic gave rise to and intensified many challenges for persons living in urban poverty in South Africa, particularly unlawful occupiers, who found

54 Id, para 58.

55 Id, para 62.

56 Id, para 63.

57 Id, paras 66-69.

58 Id, paras 70-76.

59 Id, paras 77-78.

60 See the full order in id, para 80.

61 M Langford and J du Plessis "Dignity in the rubble? Forced evictions and human rights law" (17 October 2017, Centre on Housing Rights and Evictions), available at: <https://iss uu.com/cohre/docs/cohre_dignityintherubble_humanright> (last accessed 23 June 2021). 
themselves facing the threats of eviction and the demolition of their dwellings. The impact of evictions on South Africa's urban fabric is well known and the subject of many a scholarly inquiry, while being widely understood to be deeply rooted in the country's political past and an enduring state of urban informality (a booming informal economy and widespread informal housing). ${ }^{62}$ In essence, understanding the full impact of evictions from a broader perspective on justice requires an appreciation of the notion of "consequential geography" as being "acutely manifest in cities, which have become the loci of contested spaces, particularly when legal norms and institutions are invoked to effect the eviction of impoverished communities from heavily populated urban areas". ${ }^{63}$ In a 2011 article on local government and evictions law in South Africa, Van Wyk states that "(v)ulnerable people, particularly, must be treated with care and concern and human beings must be treated as human beings", ${ }^{64}$ but in the same piece the author explains the legal complexities and uncertainty cities face when confronted with the unlawful occupation of property. ${ }^{65}$ This complexity and uncertainty may be expected to have been radically intensified by COVID-19.

In response to the plight of unlawful occupiers, the South African government promulgated emergency legislation, in the form of COVID-19 regulations that prohibited, inter alia, eviction and demolition without court orders. The Alert Level 3, 4 and 5 Regulations prohibited evictions in a generalized manner and gave the courts wide discretion on whether to stay or suspend eviction orders. However, the Alert Level 1 and 2 Regulations established more stringent requirements for the courts to consider in deciding whether to grant orders for the eviction of unlawful occupiers and the demolition of their dwellings. The requirement to procure a court order before an eviction or demolition was important in upholding the rule of law and mitigating the human suffering caused by evictions and the demolitions of residences. In cases such as Olivia Road ${ }^{66}$ and Pheko, ${ }^{67}$ the South African courts had emphasized that local authorities "are under an obligation to enforce health, safety and disaster management legislation in a manner that is compatible with their duty to prevent homelessness". ${ }^{68}$ The COVID-19 response

See, for example, M Strauss and S Liebenberg "Contested spaces: Housing rights and evictions law in post-apartheid South Africa" (2014) 13/4 Planning Theory 428 at 429; and J Van Wyk "The role of local government in evictions" (2011) 14/3 Potchefstroom Electronic Law Journal 50.

63 Strauss and Liebenberg, ibid.

64 Van Wyk "The role of local government", above at note 62 at 72.

65 Id at 66-68.

66 Occupiers of 51 Olivia Road, Berea Township and 197 Main Street Johannesburg $v$ City of Johannesburg 2008 (3) SA 208 (CC).

67 Pheko v Ekurhuleni Metropolitan Municipality 2012 (2) SA 598 (CC).

68 Strauss and Liebenberg "Contested spaces", above at note 62 at 439. See also A du Plessis and A Van der Berg "Some perspectives on constitutional conflict in local disaster management through the lens of Pheko v Ekurhuleni Metropolitan Municipality" (2012) 28/2 Southern African Public Law 448. 
of the national legislature and judiciary was thus aligned with this thinking. The true reasons for some municipalities to have pushed back in rebellion are not immediately clear and remain a point of speculation that cannot be analysed further here.

Despite the prohibitions outlined above, unlawful occupiers continued to face the threat of eviction or the destruction of their homes during the pandemic. In the City, the evictions and demolitions were unauthorized by the courts and implemented so frequently and brutally that it became necessary for some communities and the South African Human Rights Commission to take legal action in defence of vulnerable communities. The City's defence in the cases under discussion was made on environmental grounds and common law remedial action. At face value, these are sound and legitimate legal arguments, but they lose all their weight and are unconvincing against the contextual background of COVID-19, consequential geography and an expectation of spatial awareness. The court judgments in Community of Hangberg and Qolani made it clear that, even in the midst of a pandemic, observing the rule of law is essential and it is necessary to respect the constitutional rights to life, dignity, freedom and security of the person, property, an environment not detrimental to human health and well-being, and access to housing.

In both cases under discussion, the courts also reiterated the need to ensure that, when authorities evict unlawful occupiers and demolish their dwellings, they bear in mind that they are dealing with the most vulnerable members of society. The cases also showed the need to refocus scarce resources from pursuing unlawful occupiers to helping them acquire adequate housing. This speaks to the need for local authorities to rethink some of their priorities and how these find expression in typical local governance instrumentation, such as integrated development plans, budgets, budget implementation plans and performance management systems. ${ }^{69}$ Such setting of priorities may be expected to be directed by the constitutional objectives of local government and the rights and duties emanating from the notion of developmental local government. A municipality's priorities should also reflect the dynamics of mounting urban informality in South Africa and the need to evaluate critically the suitability of existing by-laws, local governance instruments and policies, as well as municipalities' methods of enforcing national legislation.

\section{CONCLUSION}

UN-Habitat and the UN Human Rights Office stated some years ago that the "(p)ost-conflict and post-disaster reconstruction or the improper use of disasters risk reduction laws or housing building standards might also become

69 For an in-depth analysis of local governance instrumentation as it finds application to issues of sustainability, see J Nel, A du Plessis and $\mathrm{W}$ du Plessis "Instrumentation for local environmental governance" in AA du Plessis (ed) Environmental Law and Local Government in South Africa (2nd ed, 2021, Juta), chap 3. 
an excuse for evicting and displacing people from their homes", noting further that "(e)victions are not an inevitable side-effect of urbanization, development and reconstruction. They are the result of human interventions". ${ }^{70}$ The South African government's response to COVID-19, by way of its emergency law and judicial interventions, has shown a remarkable appreciation of the vulnerability of urban dwellers, especially those at risk of being forcibly removed from their dwellings. The government's response signals its willingness to protect those in cities most exposed to day-to-day disruptive risk. It shows an encouraging sense of "spatial awareness". The impact that COVID-19 is having and will continue to have on poor urban communities living in and on the periphery of South Africa's cities cannot be gainsaid. The number of illegal occupiers is not expected to decrease, the socio-economic hardship of people in informal settlements will not disappear any time soon, and the compounded risks accompanying urbanization will not become any easier to address. The responsibility of the South African government is immense. The real test is going to be if and how this government will, after the end of the pandemic, address the housing deficit and service delivery challenges of those most at risk, in a sustainable and legally sound fashion. When the emergency law framework falls away, it will be up to all three spheres and branches of government to take the necessary positive action to effect lasting change.

\section{CONFLICTS OF INTEREST}

None

70 "Forced evictions" (UN-Habitat and UN Human Rights Office fact sheet no 25, 2014) at 2. 